\title{
Flood risk assessment and mapping in Abidjan district using multi-criteria analysis (AHP) model and geoinformation techniques, (cote d'ivoire)
}

\author{
Jean Homian Danumah ${ }^{1 *}$, Samuel Nii Odai ${ }^{1}$, Bachir Mahaman Saley ${ }^{2}$, Joerg Szarzynski ${ }^{3}$, Michael Thiel ${ }^{1}$, \\ Adjei Kwaku', Fernand Koffi Kouame ${ }^{2}$ and Lucette You Akpa ${ }^{2}$
}

\begin{abstract}
Background: Flood is one of the most destructive natural disasters of climate change effects in West Africa. Flood risk occurrence is a combination of natural and anthropogenic factors, which calls for a better understanding of its spatial extent. The aim of this paper is to identify, and map areas of flood risk in Abidjan district.

Results: This work is based on the integration of multi-criteria data including slope, drainage density, type of soil, Isohyet, population density, land use and sewer system density within ArcGIS interface. The resulting AHP flood risk map shows that areas under high and very high flood risk covers $34 \%$ of the study area.

Conclusion: The Analytic Hierarchy Process (AHP) method used as a multi-criteria analysis allowed the integration of several elements under two criteria, hazards and vulnerability, for flood risk assessment and mapping. Results revealed that, Abidjan district is heavily exposed to the risk of flooding. Eight out of thirteen (8/13) municipalities within the district are at a high risk of flooding which calls for decision makers to effectively develop strategies for future flood occurrences within the Abidjan district (South of Côte d'Ivoire).
\end{abstract}

Keywords: Flood risk, Multicriteria analysis, Remote sensing, Geoinformation techniques, Abidjan, Cote d'Ivoire

\section{Background}

Natural disaster is considered to be the biggest challenge that needs to be examined at global, regional and local scale. Climate change may increase the frequency, magnitude and the seasonality of extreme events such as flood, which means that concurrent flood hazard of importance to urban flood risk management, may occur more frequently in the future (Duan et al. 2015; Huong and Pathirana, 2013; Pedersen et al. 2012). Urbanization is also an important factor to increased flood risk in the cities through increasing runoffs which affect communities' downstream (Cloke et al. 2013; Duan et al. 2016). Floods are among the most devastating natural hazards in the world, claiming more lives and causing more

\footnotetext{
* Correspondence: danumahjean@yahoo.fr

${ }^{1}$ Department of Civil Engineering, Kwame Nkrumah University of Science and Technology, WASCAL PhD Program in Climate Change and Land Use, Kumasi, Ghana

Full list of author information is available at the end of the article
}

property damage than any other natural phenomena (Duan et al. 2014; Kebede, 2012; Wang et al. 2011; Forkuo, 2011; Yahaya et al. 2010; Yalcin and Akyurek 2004; Hapuarachchi et al. 2011; Tsakiris, 2014). As a result, floods are one of the greatest challenges to weather prediction (Jeyaseelan, 2003).

In Africa, the situation is very likely to worsen as the intergovernmental panel on climate change (IPCC) has projected higher frequencies and intensities of floods and droughts (IPCC, 2007) for the continent as a consequence of climate change. Floods and flash floods cause loss of life and property damage (Musungu et al. 2012). From 1900 to 2006, floods in Africa killed nearly 20,000 people, and also affected nearly 40 million more, with estimated damages of about 4 billion USD according to the ICSU Regional Office for Africa (2007). Flood is one of the most destructive natural disasters of climate change effects in West Africa (Kouassi et al. 2008). The 
demands of the growing population and related urbanization lead to severe land use change (Franci et al. 2015) and increasing flood occurrence in West Africa.

Urban floods result from blocked or inadequate storm sewers and are due to increased urbanization (Ajin et al. 2013). Urban areas have high risk of flash flooding due to the presence of large impervious areas and sometimes inefficient drainage system (Chen et al. 2009; Huong and Pathirana, 2013; Sowmya et al. 2015). Several additional phenomena commonly contribute to urban flooding, such as limited conveyance capacity of urban channels and rivers, as well as drains and sewers and infiltrationinflow, and decades of urban development without upgrading of the drainage infrastructure (Pedersen et al. 2012). The rapid growth often results in a poorly planned urbanization making urban populations increasingly vulnerable to floods.

While the primary cause of flooding is excessive rainfall (Kim and Kim, 2014), there are many other causes resulting from human activities such as: land degradation; deforestation of catchment areas; sprawl and increased population density along riverbanks (Prasad et al. 2016; Billi et al. 2015; Mbow et al. 2008; Forkuo, 2013), poor land use planning, zoning, and control of flood plain development; inadequate drainage, particularly in cities, and inadequate management of discharges from river reservoirs.

Hence, assessing and predicting floods risk has become essential to offer appropriate solutions for flood and sustainable environmental management. Flood hazard mapping is a vital component for appropriate land use planning in flood areas and mitigation measures (Bhatt et al. 2014). It provides accessible charts and maps which can be read easily and therefore, facilitates the identification of risk areas by planners and this enable them to prioritize their mitigation efforts (Bapalu and Sinha, 2005; Forkuo, 2011; Wang et al. 2011; Ajin et al. 2013).

Flood management is necessary not only because flood imposes huge damages on the society, but for the optimal exploitation of the land and its proper management. This cannot become technically feasible without effective flood hazard and risk maps (Bhatt et al. 2014)

More recently in Cote d'Ivoire, populations have experienced increasingly important phenomena of floods, with its effects such as death, damage to property and population exodus. Heavy rainfall is the main natural hazard which causes loss of many lives; destruction of infrastructures, and the displacement of people during the rainy season in Abidjan. Statistical analysis done in 2013 shows that $26 \%$ of the district of Abidjan is flood risk area and 21, 13, and 15 people died in 2009, 2010, and 2011 respectively due to floods (OCHA, 2013). Also the result indicates that, a total of 80,000 people live in areas that are subject to risk of flooding in the district with 40,000 people in Cocody, 12,500 people in Abobo, 10,000 in Adjame, 9,500 in Yopougon and 8,000 in Attecoube communes (OCHA, 2013). However, the use of multi-criteria evaluation approach to flood risk assessment and mapping in Cote d'Ivoire is still rare (Savane et al. 2003; Saley et al. 2005; Saley et al. 2013). Extreme rainfall data analysis for many years were based on determining break on the times series using some statistical methods such as Pettit and Buishand test (Lubes-Niel et al. 1998), application of Nicholson indices to bring out the wet and dry period in case of rainfall variability and shows general trend and interannual behavior (Brou, 2005; Savane et al. 2003; Goula et al. 2006; Kouassi et al. 2008).

Flood risk occurrence is a combination of natural and anthropogenic factors, which means that there is the need for knowledge about spatial extent of flooding areas, using multi data as drivers becomes a potential source for more reliable flood management and mitigation. For all that, Multi-criteria analysis (MCA) approach has become widely used (Wang et al. 2011; Sowmya et al. 2015) to solve complex problems and to assess flood risk. Many methods have been proposed for multicriteria decision making. Analytic Hierarchy Process (AHP) developed by Saaty (1980) is one of the best known and most widely used MCA approaches (Orencio \& Fujii, 2013; Yahaya et al. 2010). AHP is used to solve a broad range of multi-criteria decision-making problems, with the pairwise comparison matrix calculating the weights for each criterion considered (Yalcin, 2008; Orencio \& Fujii, 2013; Le Cozannet et al. 2013; Pourghasemi et al. 2014). AHP assumes complete aggregation among several criteria and develops a linear additive model. The uniqueness of applying AHP in different studies helps in modelling situations of uncertainty without losing subjectivity and objectivity of any evaluation measure.

Of late, considerable attention has been given to the use of AHP in natural hazard (earthquake and flood) assessment but more in flood management in various studies: (Savane et al. 2003; Yahaya et al. 2010; Cozannet et al. 2013; Orencio \& Fujii, 2013; Saley et al. 2013; Chakraborty and Joshi, 2014; Pourghasemi et al. 2014; Papaioannou et al. 2015; Nejad et al. 2015). It has been shown from these series of papers that AHP has the ability to assess and map flood risk with good accuracy. However, it is based on expert opinions and thus may be subjected to cognitive limitations with uncertainty and subjectivity (Pourghasemi et al. 2014).

The significant research gap identified by this study is that recent scientific work undertaken in the district of Abidjan concentrated on rainfall variability during past and current condition as flood risk drivers within two 
communes of Abidjan: Attecoube and Abobo (Savane et al. 2003; Hauhouot, 2008). This is a piece-meal approach and does not provide a solution to the problem of flood occurrence within the entire district. Other studies (Kouame et al. 2013; Jourda et al. 2006; Ahoussi et al. 2013) in the district did not directly focus on flood but pointed out the inefficiency of the drainage network and impervious area which are part of the main drivers of floods. However, these studies are fragmented and did not consider the entire district and multi criteria as input to link climate change and flood occurrence, no studies have yet been undertaken to evaluate and map flood risk at Abidjan district level.

The aim of this paper was to identify, and map areas of flood risk based on several factors that are relevant to flood risks in Abidjan district. For this purpose, assessment process of flood risk was conducted under hazard and vulnerability concepts within analytic hierarchy process (AHP) framework.

\section{Study area}

The district of Abidjan is located in the south of Cote d'Ivoire between latitudes of $5^{\circ} 10^{\prime}$ and $5^{\circ} 38^{\prime}$ North and longitudes of $3^{\circ} 4^{\prime}$ and $5^{\circ} 21^{\prime}$ West (Fig. 1). It consists of thirteen (13) municipalities since 2001, ten (10) municipalities in Abidjan and three (3) others town namely Bingerville, Songon and Anyama and covers an area of approximately $2,119 \mathrm{~km}^{2}$. The population is about $4,739,752$ inhabitants in the metropolis, and 4,460,355 inhabitants in the main city (INS, 2013), which represents $20.3 \%$ of the national population as it is in 2013. In addition, the

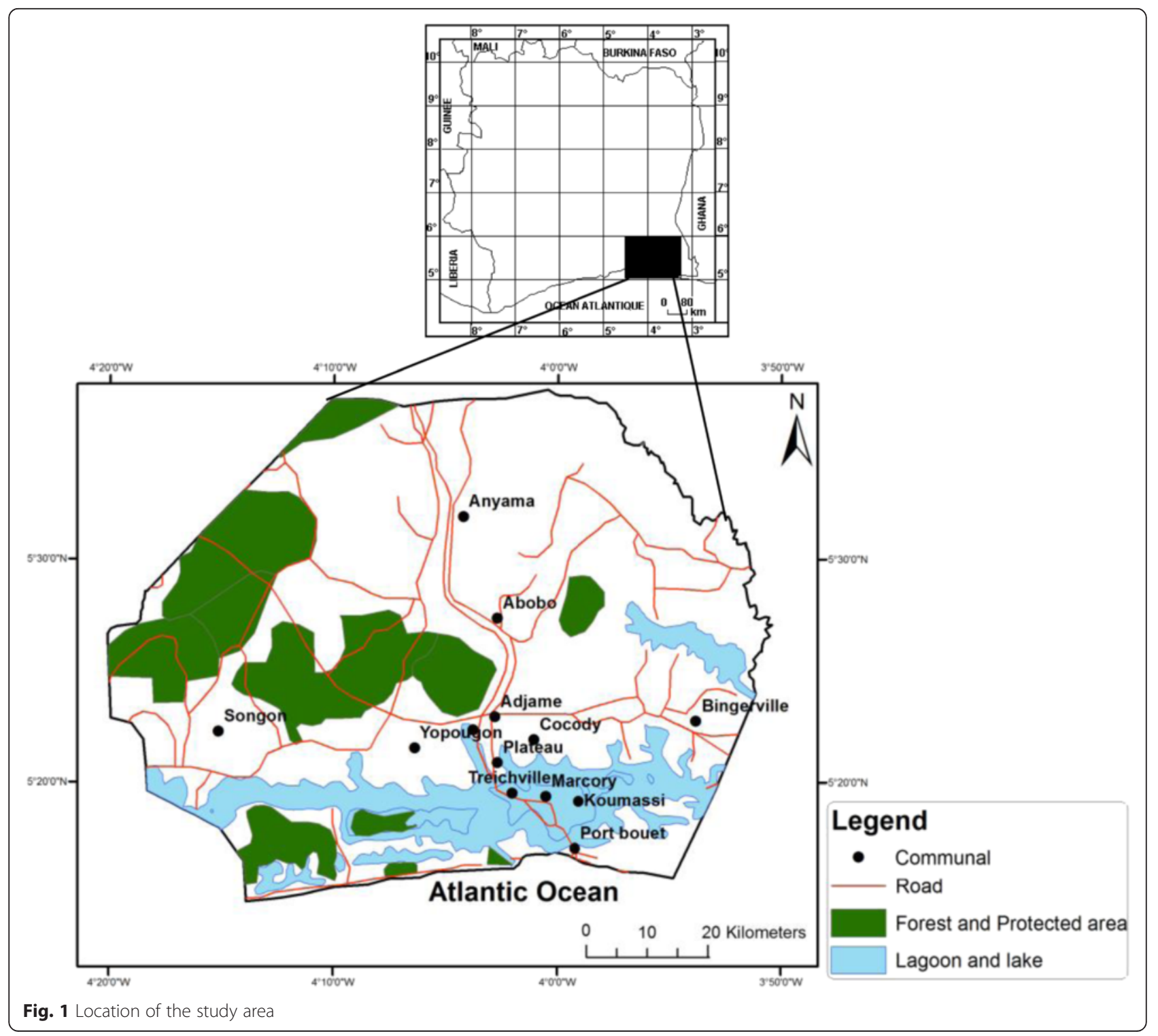


population is constant growth process mainly as a result of high industrialization, urbanization and the later political crisis. It is limited (Fig. 1):

- To the south by the Atlantic Ocean;

- In the southwest by the Department of Dabou;

- To the west by the Department of Grand Lahou;

- To the north by Agboville Department;

- In the south-east by the Department of Grand-Bassam;

- In the east by the Department of Alepe.

\section{Climatic variability}

According to Tapsoba (1997), the study area has an equatorial climate transition (Attieen Climat), characterized by four seasons: two dry seasons (December to April and August to September) and two rainy seasons (May to July and October to November) within the annual cycle:

- Long dry season from December to April;

- Long rainy season from May to July;

- Short dry season from July to September;

- Small rainy season from October to November.

\section{Precipitation}

The annual average rainfall of Abidjan was about 1873 mm from 1960 to 2012 (Fig. 2).

High annual rainfall was recorded in Abidjan district during the period 1960-2012 and ranged from $2800 \mathrm{~mm}$ in 1963 to $1020 \mathrm{~mm}$ in 1990 with an average of 1910 $\mathrm{mm}$. Generally, in 1960s, the annual rainfall ranged between 2000 and $3000 \mathrm{~mm}$. After 1987, there has been a drop in rainfall and this has oscillated between 1500 and $2200 \mathrm{~mm}$, a reduction of more than $500 \mathrm{~mm}$ compared to the 1960 s.

\section{Ombrothermic diagram}

After completing ombrothermic diagrams which shows comparison between temperature and rainfall charts of

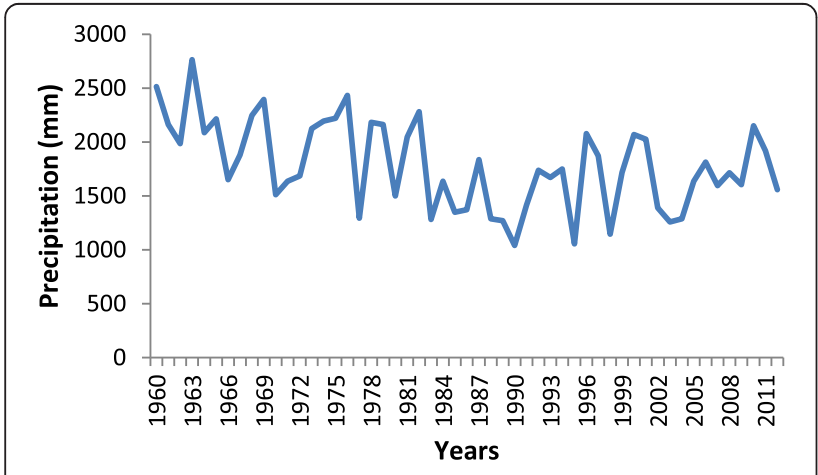

Fig. 2 Total annual rainfall variability of Abidjan from 1961-2012
Abidjan (Fig. 3) over the period 1961-2012; it was noted that, the temperatures are often low during the months of heavy rainfall and high during the months of low rainfall.

Also, observation of highest average monthly rainfall from 1960 to 2014 shows that June and sometimes May are the rainiest month of the District of Abidjan. Secondly, the temperature curve shows that the months of March and April are the hottest months with a monthly average temperature above $27{ }^{\circ} \mathrm{C}$.

\section{Analysis of the annual rainfall and the heavy rainfall month}

Graphical comparison between annual rainfall and rainiest months of the Abidjan district to analyse the trend patterns from 1960 to 2012 revealed that, in general, the annual rainfall variability is based on June's amount of rainfall because it is the highest rainfall month compared to May in the series (Fig. 4).

\section{Population growth}

Abidjan is the economic capital of Cote d'Ivoire and known for its perpetual population growth characterized by continuous uncontrolled urbanization due to demographic growth which creates gap in the context of climate change and anthropogenic impact related to safe environment and healthy life (Fig. 5).

\section{Methods}

\section{Data and material}

In this study, various basic thematic layers were created from different source including map, field study, satellite image and secondary data based on multicriteria analysis method. Using ArcGIS, Mapinfo and eCognition software tools, several maps were prepared including slope, soil, rainfall distribution, drainage density, demography, drainage system and urban structure type (land use). The drainage density and administration map were derived from the national

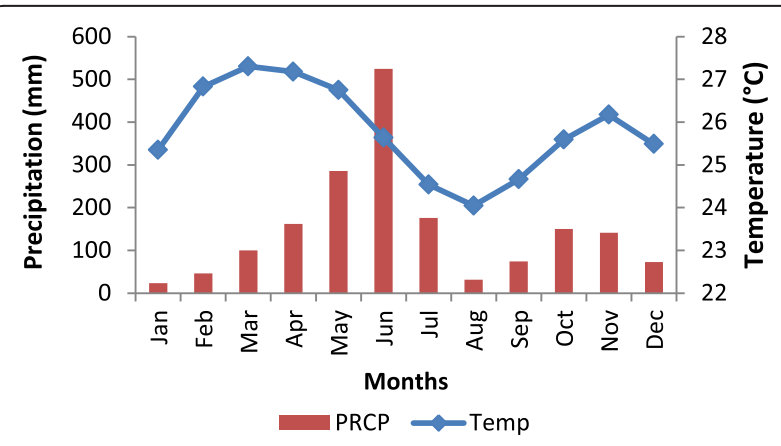

Fig. 3 Ombrothermic diagram of Abidjan District from 1981-2012 


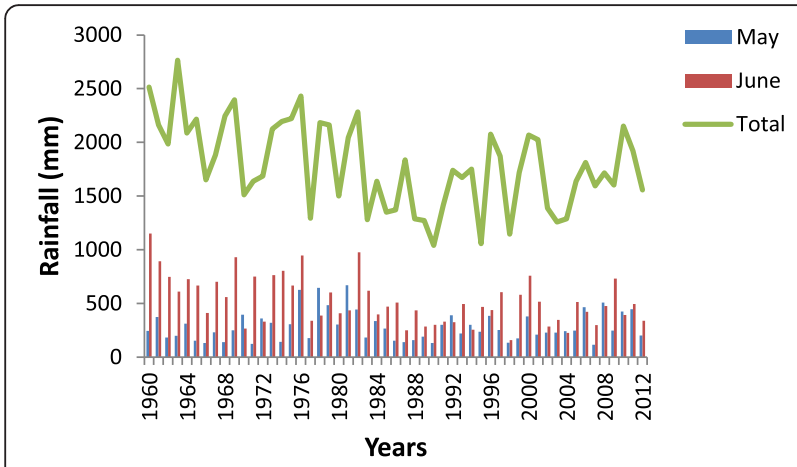

Fig. 4 Annual rainfall and heavy rain months of Abidjan from 1960-2012

center of cartography and remote sensing (CCT) and we extracted them using clip tools. Soil map was digitized based on national soil map done by ORSTOM and validated with field sample using map info software and GIS. The slope map was extracted from Aster DEM with resolution $30 \mathrm{~m}$ using spatial analyst tools. The rainfall distribution map was prepared from the national meteorological agency (SODEXAM) using Inverse distance weighted method (IDW). The urban structure types (land use) map was extracted from Spot 5 satellite imagery using eCognition software tools by applying oriented based image analysis. Population data obtained from the National Institute of Statistic (INS) was used to generate the population density map. Sewer system density map was also elaborated based on data collected from field and overlaid with the Water Company sewer system map.

\section{AHP model processing}

Analytical Hierarchy Process uses hierarchical structures to represent a problem and, then, develop priorities for alternatives based on the judgment of the user (Saaty,
1980) and is based on paired comparisons. Evaluation criteria and their weights must be determined according to their importance. The process consists of six steps (Saaty 1980).

- Breaking a complex unstructured problem down into its component factors

- Development of the AHP hierarchy

- Paired comparison matrix determined by imposing judgments

- Assigning values to subjective judgments and calculate the relative weights of each criteria

- Synthesize judgments to determine the priority variables

- Check consistency of assessments and judgments

One of the key points in AHP is calculation of consistency ratio (Saaty 1980). If consistency ratio is less of 0.1 , then the mentioned matrix can be considered as an acceptable consistency.

However, AHP approach can be summarized in three big levels.

\section{Hierarchic elaboration}

The different levels of AHP according to Saaty, 1980; Chakraborty and Joshi, 2014; Pourghasemi et al. 2014; Papaioannou et al. 2015; Nejad et al. 2015) are: level 0: main objective, in present case flood risk map; level 1: Criteria analysis which are hazard map and vulnerability map, and level 3: element considered in each criteria characteristic based on their influence (Figs. 6 and 7).

All elements under each criterion were set based on literature and the definition of hazard (physical phenomenon, natural and non- manageable) and vulnerability (degree of susceptibility and exposure due to man-made) concepts that used in this study.

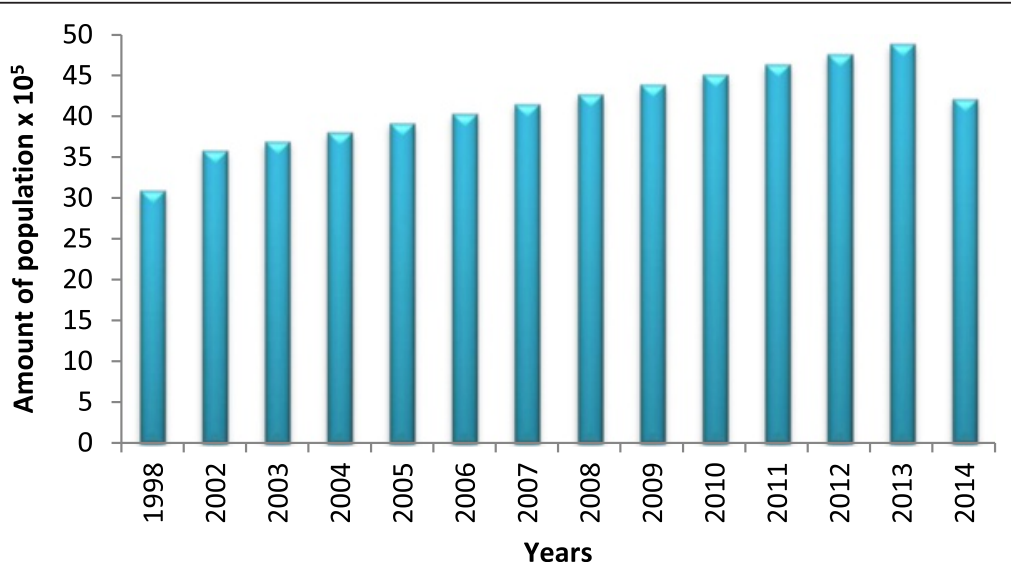

Fig. 5 Population growth of Abidjan from 1998-2014. Legend: D: drainage density; ST: soil type; S: slope; I: isohyet; UST: Urban structure type; PD: population density and DS: drainage system 


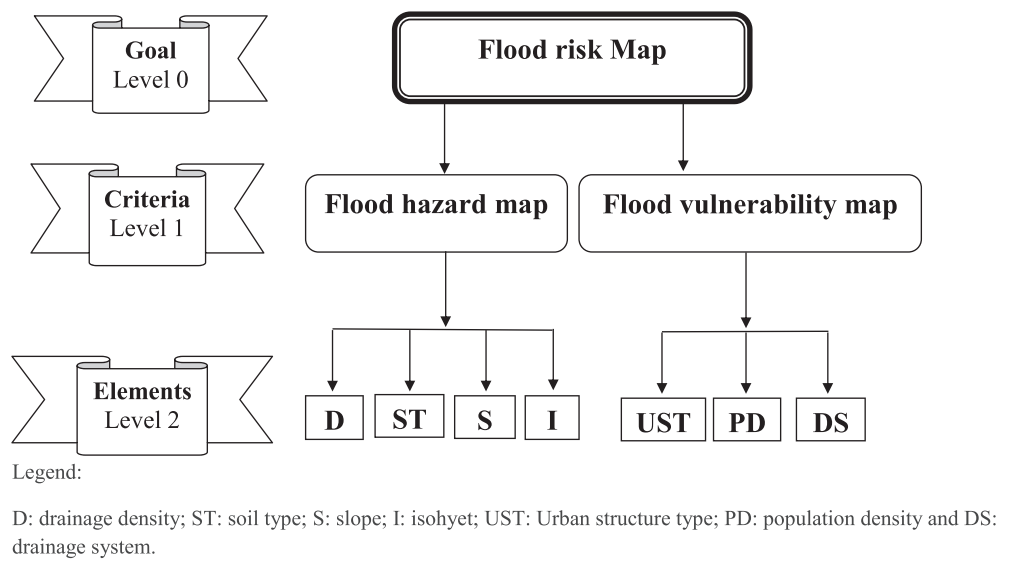

Fig. 6 AHP model use in the process flood risk map

\section{Pairwise comparison}

The binary combination is based on the scale proposed by Saaty (1980) for element comparison in Table 1. The pairwise comparison is the fundamental component of the AHP process. For each pairing within each criterion, the better option is awarded a score, again, on a scale between 1 (equally good) and 9 (absolutely better), whilst the other option in the pairing is assigned a rating equal to the reciprocal of this value. Each score records how well option "X" meets criterion "Y". Afterwards, the ratings are normalized and averaged. Ten (10) experts provide their judgment of the relative importance of one indicator against another. The pairwise comparison tables were completed by nine several experts in the field of natural disaster. Their results were normalized and examined with the Consistency Ratio test (CR).

\section{Development and prioritization matrix}

The principle of development is the following matrix:
- determine the eigenvectors $(\mathrm{Vp})$ of each criterion for each item is described in equation 1 .

$V p=\sqrt[K]{W 1 \times \ldots . \times W k}$

With k: number of parameters and compared Wk ratings main parameters;

- calculate the weighting coefficients $(\mathrm{Cp})$, the formula is given in equation 2 .

$$
C p=\frac{V p}{V p 1+\ldots .+V p k}
$$

The sum of $\mathrm{Cp}$ of all parameters of a matrix must be equal to 1 (one).

- normalize the matrix by dividing each element by the sum of a column of the column ;

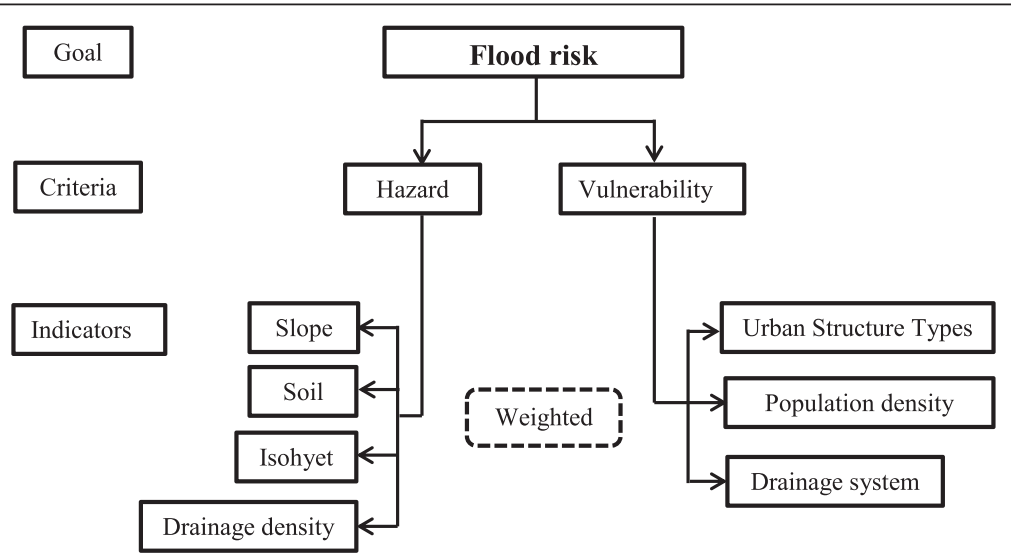

Fig. 7 Hierarchy of flood risk assessment 
Table 1 Saaty scale for various elements comparison Saaty (1980)

\begin{tabular}{lll}
\hline Scale & Judgment of preference & Description \\
\hline 1 & Equally important & Two factors contribute equally to the objective \\
3 & Moderately important & Experience and judgment slightly favour one over the other \\
5 & Important & Experience and judgment strongly important favour one over the other \\
7 & Very strongly important & Experience and judgment strongly important favour one over the other \\
9 & Extremely important & The evidence favouring one over the other is of the highest possible validity \\
$2,4,6,8$ & Intermediate preference between adjacent scales & When compromised is needed \\
\hline
\end{tabular}

- averaging each line to determine the priority vector $[\mathrm{C}]$;

- multiply each column of the matrix by the priority vector corresponding there to determine the overall priority [D];

- Divide each global priority by the priority vector corresponding to it to determine the rational priority $[\mathrm{E}]$;

- Determine the maximum Eigen value $(\lambda \max )$ by equation 3 :

$\lambda \max =\frac{[E]}{k}$

- Calculate the consistency index (CI) expressed by equation 4:

$C I=(\lambda \max -k) /(k-1)$

- Determine the consistency ratio (CR) using equation 5. The ratio of coherence can be interpreted as the probability that the croak is completed in a random manner. In fact, the responses often have a certain degree of incoherence. The AHP method does not require that judgments are consistent or transitive, indeed, Saaty (1980) has defined the value of consistency ratio. In the case where the value of consistency ratio is less than $10 \%$, the judgment is consistent and when it exceeds $10 \%$, the assessments may require some revisions.

$$
C R=\frac{C I}{R I}
$$

(RI) is the random index. Values (RI) are shown in Table 2 .

\section{AHP hazard map}

Hazard is considered a physical phenomenon, natural and non- manageable, occurrence data and intensity that can cause damage by overflow stream and the extension of the field in the water flood. Hazard refers also to hydro climatic phenomena and their impact on the flow of water. Geomorphological characteristics including slope, drainage density, soil types (Meraj et al. 2013) and rainfall (because it is the intense rainfall that triggered flooding) are the various factors taken into account in the mapping of the hazard. The hazard map will show all areas susceptible to be flooded. Crossing parameters will map the spatial extent and potentially exposed areas to climatic hazards that can cause flooding. Based on Saaty scale, different weight has been attributed to determine hazard. See below, an example of calculation of the eigenvector $(\mathrm{Vp})$ and the weighting coefficient $(\mathrm{Cp})$ of the drainage density. The weight assign to each element to determine Hazard are in Tables 3 and 4.

$$
\mathrm{Vp}=\sqrt[4]{1 \times 3 \times(1 / 3) \times 1 / 5}=0.67 \quad \text { and } \quad \mathrm{Cp}=\frac{0.67}{4.95}=0.13
$$

The relative hazard map is obtained by the given formula:

$$
\begin{aligned}
\text { Hazard index }= & 0.13 \times D+0.08 \times T S+0.26 \\
& \times S+0.52 \times I
\end{aligned}
$$

where D = Drainage density; TS = Type of Soil, $\mathrm{S}=$ slope and I = Isohyet (rainfall)

\section{AHP vulnerability map}

Vulnerability expresses the level of foreseeable consequences of a natural phenomenon on issues (Mate, 2001) and on the other hand is the most crucial component of risk in that it determines whether or not exposed to a hazard constitutes a risk (Ouma \& Tateishi, 2014). Flood vulnerability mapping is the process of determining the degree of susceptibility and exposure given place

Table 2 Random index matrix of the same dimension (Saaty 1980)

\begin{tabular}{lllllllllll}
\hline Number of criteria & 2 & 3 & 4 & 5 & 6 & 7 & 8 & 9 & 10 \\
\hline $\mathrm{Rl}$ & 0.00 & 0.58 & 0.90 & 1.12 & 1.24 & 1.32 & 1.41 & 1.45 & 1.49 & 1.51 \\
\hline
\end{tabular}

Number of criteria $=$ number of parameters compared 
Table 3 Hazard matrix

\begin{tabular}{lllllll}
\hline & $\mathrm{D}$ & $\mathrm{TS}$ & $\mathrm{S}$ & $\mathrm{I}$ & $V_{\mathrm{P}}$ & $\mathrm{C}_{\mathrm{p}}$ \\
\hline $\mathrm{D}$ & 1 & 3 & $1 / 3$ & $1 / 5$ & 0.67 & 0.13 \\
Ts & $1 / 3$ & 1 & $1 / 3$ & $1 / 5$ & 0.38 & 0.08 \\
$\mathrm{~S}$ & 3 & 3 & 1 & $1 / 3$ & 1.31 & 0.26 \\
$\mathrm{I}$ & 3 & 5 & 3 & 1 & 2.59 & 0.52 \\
Sum & 7.33 & 12 & 4.66 & 1.73 & 4.95 & 1 \\
\hline
\end{tabular}

to flooding. These issues include people, goods and socio-economic activities likely to be affected both quantitatively and qualitatively by a natural phenomenon. In this study, the vulnerability to flooding consists of three criteria: population density, drainage system and land use. The weight assign to each element to determine the vulnerability extent are in Table 5.

The relative map of vulnerability of the land to flood is obtained from the formula:

$$
\begin{aligned}
\text { Vulnerability index }= & 0.26 \times U S T+0.64 \\
& \times P D+0.1 \times D S
\end{aligned}
$$

where UST = Urban Structure Types; PD = Population Density, DS $=$ Drainage System

\section{Mapping of flood risks}

A flood risk map is a result of the combination of two components: Hazard and vulnerability (Ouma \& Tateishi, 2014; Yagoub, 2015). This model is suitable for most natural hazards and is given by this equation 7 :

$$
\text { Risk }=\text { Hazard index } \times \text { Vulnerability index }
$$

In this study, weight were assigned to the different thematic indicators classes and layers based on their relative influence and contribution to the hazard and vulnerability. The overlay technique was employed to the indicators to determine hazard and vulnerability first of all and by crossing hazard and vulnerability to obtain the goal which is flood risk area identification and zoning. All processes were done in ArcGIS using raster calculator in spatial analyst tools.

\section{Results and discussion}

\section{Hazard map}

The hazard map obtained highlights five areas as shown in Fig. 8. The very low and low classes cover $22.42 \%$ and $30.67 .5 \%$ respectively of Abidjan. It is essentially areas with high slope, low drainage density and low precipitation amount. The medium class represent $15.41 \%$ include Yopougon and Abobo municipalities but is around areas of high and very high hazard. The classes of high and very high hazard are estimated to $15.34 \%$ and $16.16 \%$ respectively cover most of Abidjan municipalities (Adjame, Plateau, Cocody, Treichville, Koumassi, Port-Bouet, marcory, Attecoube and Bingerville) numbering nine out of thirteen (9/13) municipalities. All these areas are within high and very high hazard zones and are dominated by low slope, significant occurrence of rainfall, tertiary sand, ferralitic soil strongly desaturated and low drainage within the Abidjan district.

\section{Vulnerability map}

The vulnerability map obtained by combining land use, population density and drainage system highlights five areas (very low to very high) as shown in Fig. 9. Very low and low classes cover $24.34 \%$ and $21.63 \%$ respectively of Abidjan. It is essentially areas with vegetation, cropland, less population density, good drainage system, industrial area and high residence area. Medium class represents $29.89 \%$ and covers most of Abidjan municipalities (Anyama, Plateau, Treichville, Port-Bouet, Marcory, and Bingerville) around six out of thirteen (6/13) municipalities. Areas covered by high and very high classes of vulnerability are $14.59 \%$ and $09.55 \%$ respectively. Analysis showed that all these areas covered by high and very high vulnerability are dominated by poor drainage systems, high population density and impervious area (Abobo, Yopougon, Attecoube, Koumassi and some area in Cocody) within the Abidjan district.

\section{Flood risk}

The risk of flooding resulting map in Fig. 10, defines five levels of risk, ranging from very low to very high. Areas with very low, low and medium risk of flooding cover respectively $5.23 \%, 24.37 \%$ and $36.31 \%$ of Abidjan. They are unevenly distributed and characterized by high slope,

\begin{tabular}{|c|c|c|c|c|c|c|c|c|c|c|c|}
\hline & $D$ & Ts & $S$ & I & $\sum$ of rows & {$[\mathrm{C}]$} & {$[\mathrm{D}]=[\mathrm{A}]^{*}[\mathrm{C}]$} & {$[E]=[D] /[C]$} & $\lambda \max$ & $\mathrm{Cl}$ & $C R$ \\
\hline $\mathrm{D}$ & 0.14 & 0.25 & 0.07 & 0.12 & 0.58 & 0.15 & 0.58 & 3.87 & & & \\
\hline Ts & 0.04 & 0.08 & 0.07 & 0.11 & 0,3 & 0.08 & 0.32 & 4 & 4.09 & 0.03 & 0.03 \\
\hline S & 0.41 & 0.25 & 0.21 & 0.19 & 1.06 & 0.26 & 1.12 & 4.31 & & & \\
\hline | & 0.41 & 0.42 & 0.64 & 0.58 & 2.05 & 0.51 & 2.14 & 4.20 & & & \\
\hline Sum & 1 & 1 & 1 & 1 & 3.99 & 1 & & 16.38 & & & \\
\hline
\end{tabular}
vegetation and cropland areas and low population

Table 4 Normalization of hazard matrix

*mean multiply 
Table 5 Vulnerability matrix

\begin{tabular}{lllllllll}
\hline & LU & PD & DS & $V_{p}$ & $C_{p}$ & $\lambda_{\max }$ & $C l$ & $C R$ \\
\hline LU & 1 & $1 / 3$ & 3 & 1 & 0.26 & & & \\
PD & 3 & 1 & 5 & 2.47 & 0.64 & & & \\
DS & $1 / 3$ & $1 / 5$ & 1 & 0.4 & 0.1 & $\mathbf{3 . 0 3}$ & $\mathbf{0 . 0 2}$ & $\mathbf{0 . 0 3}$ \\
Sum & 4.33 & 1.53 & 9 & 3.87 & 1 & & & \\
\hline
\end{tabular}

density. Areas with high and very high risks cover 19.97 $\%$ and $13.92 \%$ respectively. An overall area of high and very high risk of flooding covers $34 \%$ of the study area. Municipalities identified to be at high and very high risk of flooding within the Abidjan district are Abobo, Yopougon, Adjame, Attecoube, Koumassi, Port-bouet, Marcory, Treichville and some area of Cocody. The analysis of this map show also that the urban structure types play really a key role in addition to population density,

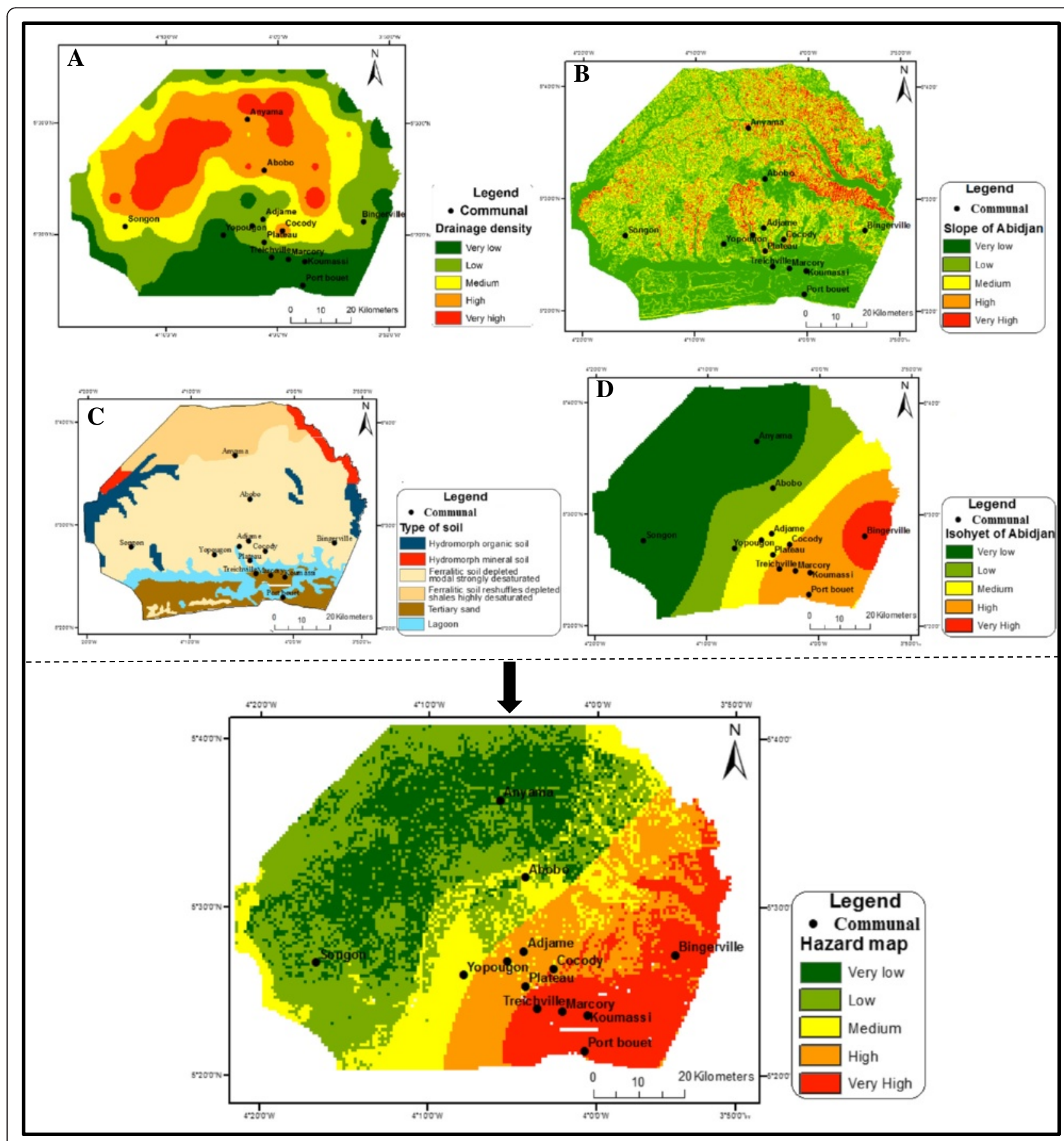

Fig. 8 Hazard map of Abidjan. a Drainage density map, b Slope map, c Type of soil map and $\mathbf{d}$ Isohyet map 


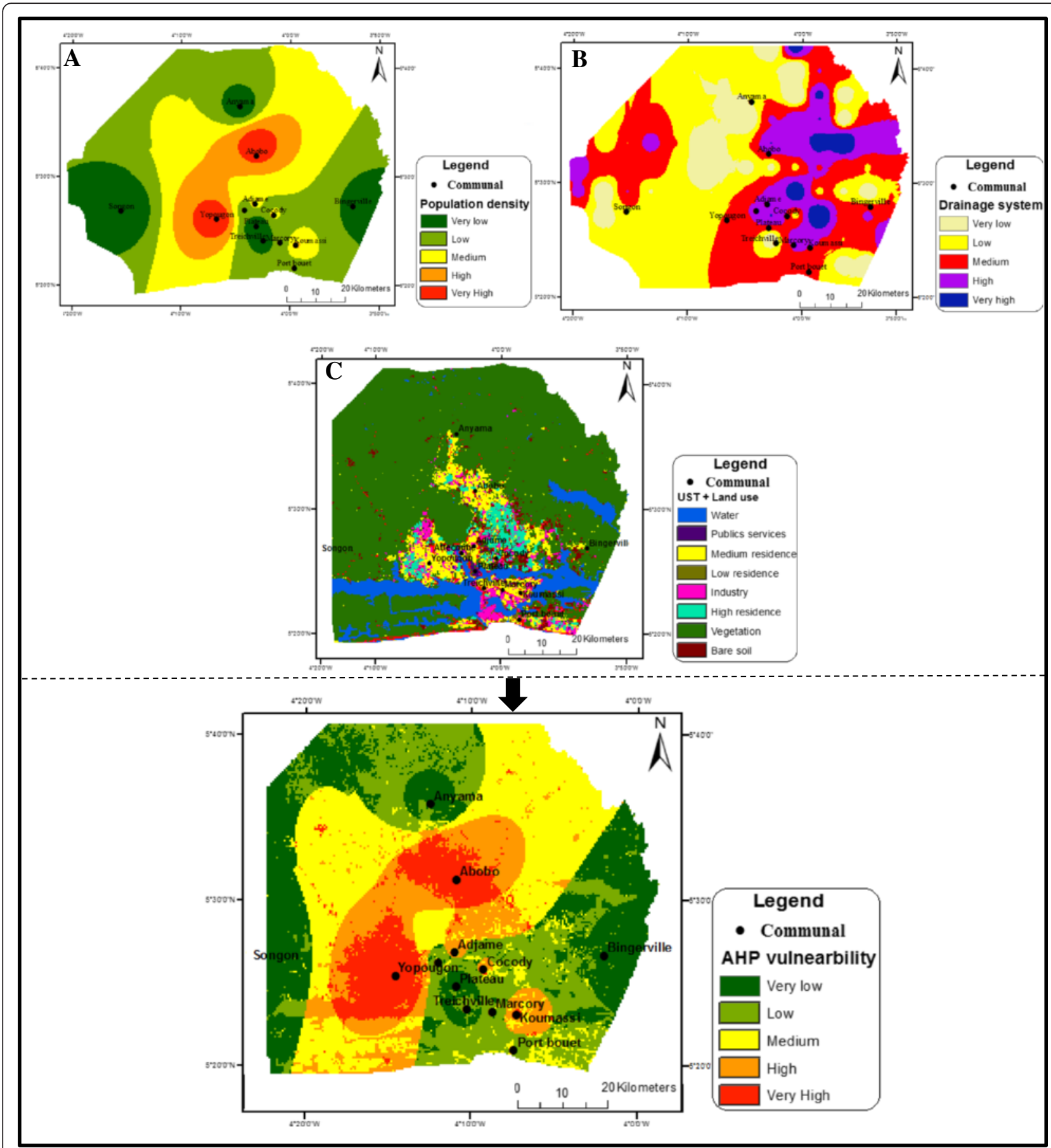

Fig. 9 Vulnerability map of Abidjan. a Population density map, b Drainage system map and c Urban Structure Types

flat slope and heavy rainfall into the risk of flooding in Abidjan; as well as other anthropogenic factors (uncontrolled urbanization) showing morphology level play an aggravating role in the risk of flooding.

\section{Discussion}

Abidjan district flood risks was evaluated using multicriteria analysis approach specifically AHP, combining vulnerability and hazard assessment. The flood risk was around $70 \%$ when the study summed moderate, high and very high classes. The analysis shows that $34 \%$ of the study area is flood risk zone, but from critical analysis most of the communal areas are high flood risk areas whiles the low and very low classes are vegetation areas with few population and urbanization. Eight out of thirteen (8/13) municipalities of Abidjan district are at a 


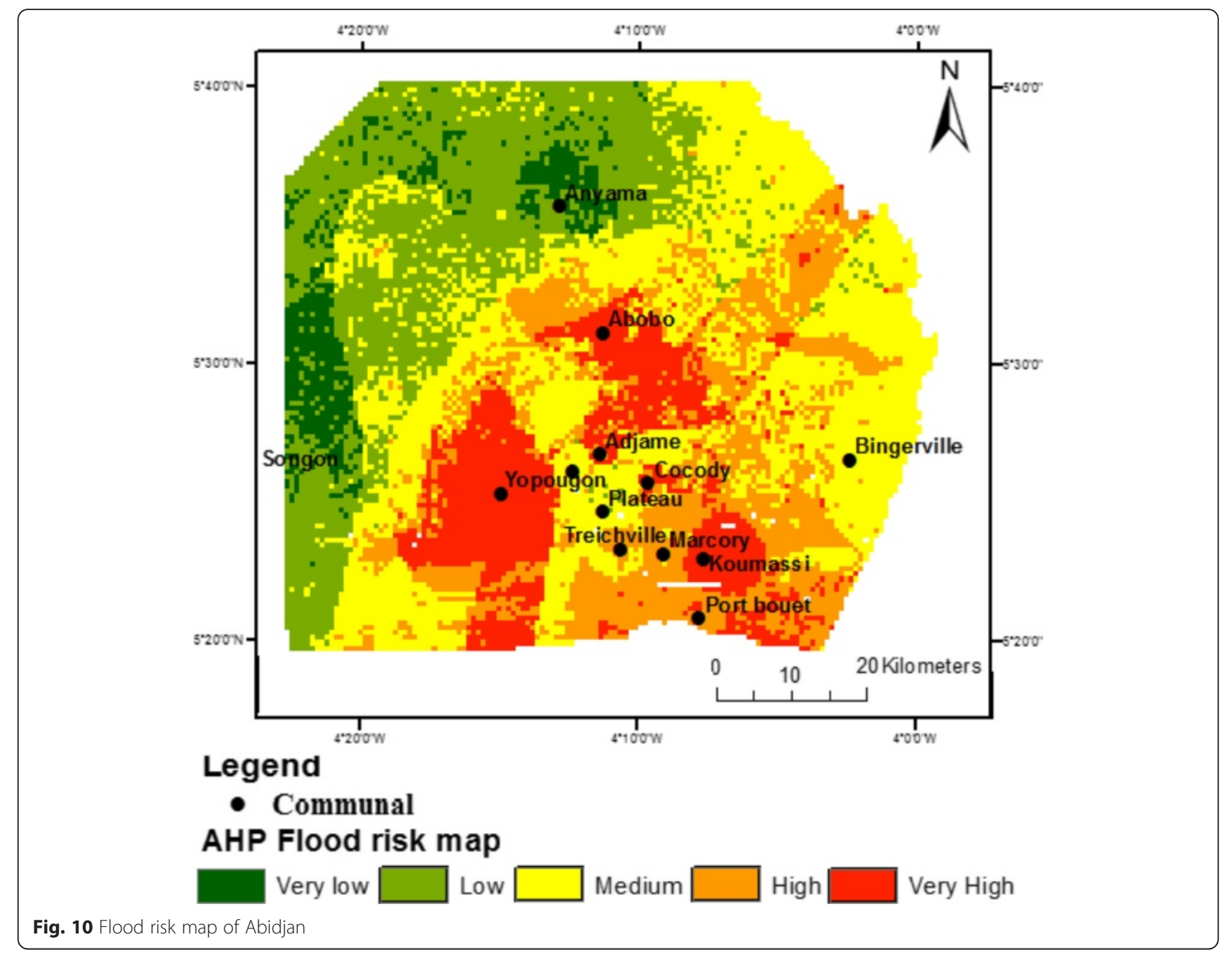

high risk of flood and therefore need optimal design of technical solutions from society. The reliability of the resulting flood risk map which gives acceptable results is based on input parameters, historical and recorded flood data. Results from the hazard map showed $32 \%$ of the area as high hazard risk with rainfall and slope being the most significant causative factors in flood occurrence. The vulnerability map also showed $24 \%$ of the area as highly vulnerable to flood with population density and land use through urban structure types as relevant factors in flood risk.

Multi-criteria analysis (AHP) adopted for this study within Abidjan district facilitated multi-source data combinations, which constituted a real advantage. The method is based on physical, hydrogeological and anthropogenic parameters. The parameters used in the flood risk map include slope, drainage density, soil, rainfall, system of evacuation, demography and land use which are the combination of hazard and vulnerability require interpolations to allow their crossing. Results indicated that AHP can be used as an efficient method to assess and map flood risk in GIS environment. AHP methodology allowed a better understanding of all the element or indicator contributions in flood process based on weight given to each of them. However, coming from different sources, interpolating and crossing data in GIS at the same resolution are factors of some bias during the processing and analysis. Normalization and weighted steps of these parameters are important to reduce bias and uncertainty in the final result. Also, AHP method shows some failure due to the subjectivity in choosing the value of the indicator weighting from arbitrary judgments of experts (Papaioannou et al. 2015). This weakness is reduced by the consistency ratio test of judgments. Saaty, 1980 provides a consistency ratio threshold which must be less than $10 \%$ to make a coherent judgment. The value of consistency ratio as part of this study is $3 \%$ and the study concludes that, its judgments can be considered coherent.

But the use of other standardization approach such as linear instead of natural break (Jenks) can be improved for map comparison and accuracy assessment purposes. 
This methodological approach was inspired by various previous work (Saley et al., 2013; Saley et al. 2005; Mbow et al., 2008; Cozannet et al., 2013; Orencio, and Fujii, 2013; Chakraborty and Joshi, 2014; Pourghasemi et al., 2014; Papaioannou et al., 2015; Nejad et al., 2015) and it is clear that the risk of flooding is linked to combined action of many different factors under two criteria: hazard and vulnerability. However, the results can be improved by the development of urban structure types (UST) through oriented based image analysis (OBIA) method using high-resolution images (Ikonos, RapidEye, QuickBird) to raise classification details on urban morphology with good accuracy. Hydrologic modeling in 2D or 3D for efficient processing and management of floods (Zazo et al., 2015) can be added.

\section{Conclusion}

The multi-criteria analysis approach used in mapping areas at risk of flood required a combination of hazard map (slope, drainage, soil type and isohyet) and vulnerability map (population, sewer system density and UST). The resulting map indicates that, $34 \%$ of the study area is of high flood risk. In view of the results obtained, the Abidjan district is heavily exposed to the risk of flooding. Thus, this resultant map can serve as a guideline to decision makers for potential anticipatory measures, better land use planning and flood risk management under climate change.

Strict measures needs to be taken concerning the uncontrolled urbanization and the occupation of areas that has proximities of rivers and places of clogged water passages to be implemented by policy makers in order to prevent more significant damages. The identified areas as a high risk require more detailed mapping with the use of high spatial resolution satellite images to constitute a research perspective that can improve and refine the results obtained. This study also put in evidence the reliability and the irrefutable role play by geoinformation techniques in natural disaster assessment which requires the contribution of multi-source data.

\section{Acknowledgments}

We are grateful for the financial support provided by the German Federal Ministry of Education and Research (BMBF) under the auspices of the West African Science Service Centre for Climate Change and Adapted Land Use (WASCAL) project. We are also grateful to the WASCAL GRP-CCLU, Kumasi, Ghana.

\section{Authors' contributions}

JHD collected data from various sources, performed the assessment and drafted the manuscript. BMS, SNO, JS, FKK provided skills development, comments and suggestions during data generation, analysis, and results interpretation. MT provided software and methods guidance to develop urban structure type (UST) classification. AK and LYA helped to draft the manuscript. All authors read and approved the final manuscript.

\section{Competing interests}

I declare and certify that this research article is for pure academic purpose. In fact, it is one specific objective of my PhD research. Therefore, there is a non-financial competing interest.

\section{Author details}

'Department of Civil Engineering, Kwame Nkrumah University of Science and Technology, WASCAL PhD Program in Climate Change and Land Use, Kumasi, Ghana. ${ }^{2}$ Centre Universitaire de Recherche et d'Application en Télédétection (CURAT), Laboratoire Associé Francophone (LAF n 401), UFR des Sciences de la Terre et des Ressources Minières, Université Felix Houphouët Boigny, 22 BP 801, Abidjan 22, Côte d'Ivoire. Institute for Environment and Human Security (UNU-EHS), United Nations University, UN Campus, Platz der Vereinten Nationen 1, 53113 Bonn, Germany.

Received: 17 February 2016 Accepted: 11 May 2016

Published online: 20 May 2016

\section{References}

Ahoussi, K.E., S. Loko, Y.B. Koffi, G. Soro, Y.M.S. Oga, and N. Soro. 2013. Evolution spatio-Temporelle Des Teneurs en Nitrates Des Eaux Souterraines De La Ville d'Abidjan (CÔTE D'IVOIRE). International Journal of Pure \& Applied Bioscience 1(3): 45-60.

Ajin, R.S., R.R. Krishnamurthy, M. Jayaprakash, and P.G. Vinod. 2013. Flood hazard assessment of Vamanapuram River Basin, Kerala, India: An approach using Remote Sensing \& GIS techniques. Advances in Applied Science Research 4(3): 263-274.

Bapalu, G. V., and Sinha, R. 2005. GIS in flood hazard mapping: a case study of Kosi River Basin, india. GIS Development Weekly 1(13):1-3.

Bhatt, G.D., K. Sinha, P.K. Deka, and A. Kumar. 2014. Flood Hazard and Risk Assessment in Chamoli District, Uttarakhand Using Satellite Remote Sensing and GIS Techniques. International Journal of Innovative Research in Science, Engineering and Technology 3(8): 9.

Billi, P., Y.T. Alemu, and R. Ciampalini. 2015. Increased frequency of flash floods in Dire Dawa, Ethiopia: Change in rainfall intensity or human impact? Natural Hazards 76: 1373-1394. doi:10.1007/s11069-014-1554-01-22.

Brou, Y.T. 2005. Climat, mutations socio-économiques et paysages en Côte d'Ivoire, 212. France: Mém. HDR, Univ. Sci. Techn. Lille.

Chakraborty, A. and Joshi, P. K. 2014. Mapping disaster vulnerability in India using analytical hierarchy process. Geomatics, Natural Hazards and Risk, 20. doi:10.1080/19475705.2014.897656

Chen, J., A.A. Hill, and L.D. Urbano. 2009. A GIS-based model for urban flood inundation. Journal of Hydrology 373: 184-192.

Cloke, H.L., F. Wetterhall, Y. He, J.E. Freer, and F. Pappenberger. 2013. Modelling climate impact on floods with ensemble climate projections. Quarterly Journal of the Royal Meteorological Society 139(671): 282-297.

Duan, W., B. He, K. Takara, P. Luo, D. Nover, Y. Yamashiki, and W. Huang. 2014. Anomalous atmospheric events leading to Kyushu's flash floods, July 11-14, 2012. Natural Hazards 73(3): 1255-1267.

Duan, W., B. He, K. Takara, P. Luo, M. Hu, N.E. Alias, and D. Nover. 2015. Changes of precipitation amounts and extremes over Japan between 1901 and 2012 and their connection to climate indices. Clim Dynam 45: 2273-2292.

Duan, W., He, B., Nover, D., Fan, J., Yang, G., Chen, W., Meng, H., and Liu, C. 2016. Floods and associated socioeconomic damages in China over the last century. Natural Hazards: 1-13.

Forkuo, E.K. 2011. Flood Hazard Mapping using Aster Image data with GIS. International journal of geomatics and geosciences 1(4): 19.

Forkuo, E.K. 2013. The use of digital elevation models for water-shed and flood hazard mapping. International journal of remote sensing and geosciences 2(2): 10.

Franci, F., Mandanici, E. and Bitelli, G. 2015. Remote sensing analysis for flood risk management in urban sprawl contexts. Geomatics, Natural Hazards and Risk, 6(5-7):583-599.

Goula, B.T.A., V.J. Kouassi, and I. Savané. 2006. Impacts du changement climatique sur les ressources en eau en zone tropicale humide: cas du bassin versant $d u$ Bandama en Côte d'Ivoire. Agronomie Africaine 18(1): 1-11.

Hapuarachchi, H.A.P., Q.J. Wang, and T.C. Pagano. 2011. A review of advances in flash flood forecasting. Hydrological Processes 25: 2771-2784.

Hauhouot, C. 2008. Analysis of the rainfall risks in the precarious districts of Abidjan: Survey of cases in Attécoubé. Geo-Eco-Trop 2008(32): 75-82.

Huong, H.T.L., and A. Pathirana. 2013. Urbanization and climate change impacts on future urban flooding in Can Tho city, Vietnam. Hydrology and Earth System Sciences, 17(1): 379-394.

ICSU Regional Office for Africa. 2007. Natural and Human-induced Hazards and Disasters in sub-Saharan Africa, 32 
IPCC. 2007. Climate Change 2007: Synthesis Report. Contribution of Working Groups I, II and III to the Fourth Assessment Report of the Intergovernmental Panel on Climate Change. ed. Core Writing Team, Pachauri, R. K., and Reisinger, A, 104. Geneva, Switzerland: IPCC.

Jeyaseelan, A. T. 2003. Droughts and floods assessment and monitoring using remote sensing and GIS. Satellite remote sensing and GIS applications in agricultural meteorology, 291

Jourda, J. P., Kouamé, K. J., Saley, M. B., Kouamé, K. F., Kouadio, B. H., and Kouamé, K. 2006. A new cartographic approach to determine the groundwater vulnerability of the Abidjan aquifer. In Groundwater pollution in Africa, 103-114

Kebede B. 2012. Application of GIS and Remote Sensing Techniques for Flood Hazard and Risk Assessment: The Case of Dugeda Bora Woreda of Oromiya Regional State, Ethiopia. Paper for the 2012 Berlin Conference on the Human Dimensions of Global Environmental Change, 17

Kim, B. S. and Kim, H. S. 2014. Evaluation of flash flood severity in Korea using the modified flash flood index (MFFI). Journal of Flood Risk Management 13. doi:10.1111/jfr3.12057

Kouame, K.J., J.P. Jourda, M.B. Saley, S.K. Deh, A.T. Anani, and J. Biémi. 2013. Mapping of groundwater vulnerability zones to pollution in various hydrogeological environments of Côte d'Ivoire by drastic method. International Journal of Scientific \& Engineering Research 4(5): 9.

Kouassi, A.M., K.F. Kouamé, B.T.A. Goula, T. Lasm, J.E. Paturel, and J. Biémi. 2008. Influence de la variabilité climatique et de la modification de l'occupation du sol sur la relation pluie-débit a partir d'une modélisation globale du bassin versant du N'zi (Bandama) en Côte d'Ivoire. Rev Ivoir. Sci. Technol. 11: 207-229.

Le Cozannet G, Garcin M, Bulteau T, Mirgon C, Yates M, Méndez M, Baills A, Idier D and Oliveros C (2013) An AHP-derived method for mapping the physical vulnerability of coastal areas at regional scales. Natural Hazards and Earth System Sciences, 13:1209-1227.

Lubes-Niel, H., J.M. Masson, J.E. Paturel, and E. Servat. 1998. Variabilité climatique et statistiques. Etude par simulation de la puissance et de la robustesse de quelques tests utilisés pour vérifier l'homogénéité de chroniques. Revue des sciences de l'eau 3: 383-408.

Mbow, C., A. Diop, A.T. Diaw, and C. I. Niang. 2008. Urban sprawl development and flooding at Yeumbeul suburb (Dakar-Senegal), African Journal of Environmental Science and Technology 2(4): 075-088.

Meraj, G., S.A. Romshoo, A.R. Yousuf, S. Altaf, and F. Altaf. 2015. Assessing the influence of watershed characteristics on the flood vulnerability of Jhelum basin in Kashmir Himalaya. Natural Hazards 77: 153-175. doi:10.1007/s11069-015-1605-1.

Musungu, K., S. Motala, and J. Smit. 2012. Using multi-criteria evaluation and GIS for flood risk analysis in informal settlements of Cape Town: the case of Graveyard Pond. South African Journal of Geomatics 1(1): 92-108.

Nejad, A. R. V., Esmaeili S., and Aghamohammadi, H. 2015. Earthquake Risk Modeling using GIS for urban buildings, Case study: Tehran Municipality, District 3. Advances in Natural \& Applied Sciences 9(1): 33-43.

OCHA. 2013. http://www.unocha.org/cotedivoire/maps-graphics/thematic-maps

Orencio, P.M, and M. Fujii. 2013. A localized disaster-resilience index to assess coastal communities based on an analytic hierarchy process (AHP). International Journal of Disaster Risk Reduction 3: 62-75.

Ouma, Y.O and R. Tateishi. 2014. Urban flood vulnerability and risk mapping using integrated multi-parametric AHP and GIS: Methodological overview and case study assessment. Water, 6(6): 1515-1545.

Papaioannou, G., L. Vasiliades, and A. Loukas. 2015. Multi-Criteria Analysis Framework for Potential Flood Prone Areas Mapping. Water Resource Management 29: 399-418. doi:10.1007/s11269-014-0817-6.

Pedersen, A.N., P.S. Mikkelsen, and K. Arnbjerg-Nielsen. 2012. Climate changeinduced impacts on urban flood risk influenced by concurrent hazards. Journal of Flood Risk Management 5: 203-214.

Pourghasemi, H.R., M. Beheshtirad, and B. Pradhan. 2014. A comparative assessment of prediction capabilities of modified analytical hierarchy process (M-AHP) and Mamdani fuzzy logic models using Netcad-GIS for forest fire susceptibility mapping. Geomatics, Natural Hazards and Risk: 1-25.

Prasad, A.S., B.W. Pandey, W. Leimgruber, and R.M. Kunwar. 2016. Mountain hazard susceptibility and livelihood security in the upper catchment area of the river Beas, Kullu Valley, Himachal Pradesh, India. Geoenvironmental Disasters 3(1): 1-17.

Saaty, T. L. 1980. The Analytic Hierarchy Process: Planning, Priority setting, Resource allocation, Mc Graw-Hill, New York, 19
Saley, M.B., K.F. Kouamé, M.J. Penven, J. Biémi, and B.H. Kouadio. 2005. Cartographie des zones à risque d'inondation dans la région semimontagneuse à l'Ouest de la Côte d'Ivoire : Apports des MNA et de l'imagerie satellitaire. Teledetection 5(1-2-3): 53-67.

Saley, M.B., J.H. Danumah, V.M. Sorokoby, F.O. Kanohin, D. Atcheremi, S.P. Denean, F.K. Kouame, and V.E. Djagoua. 2013. Méthodologie pour la cartographie des zones vulnerables a l'inondation par systeme d'information géographique et analyse multicritère: application au bassin versant de la Davo a Sassandra (sud-ouest de la Cote d'Ivoire). Africa Geoscience Review 20(1): 21-33.

Savane, I., N. Coulibaly, and N. Soro. 2003. Analyse multicritère spatiale pour l'identification de la vulnérabilité aux risques naturels d'Abobo (banlieue de la ville d'Abidjan, Côte d'Ivoire). Rev. Ivoir. Sci. Technol 4: 94-107.

Sowmya, K., C.M. John, and N.K. Shrivasthava. 2015. Urban flood vulnerability zoning of Cochin City, southwest coast of India, using remote sensing and GIS. Natural Hazards 75: 1271-1286.

Tapsoba, D. 1997. Caractérisation événementielle des régimes pluviométriques Ouest-Africains et de leur récent changement. Thèse Univ. Paris XI, France, 145.

Tsakiris, G. 2014. Flood risk assessment: concepts, modelling, applications. Natural Hazards Earth System Sciences 14: 1361-1369. doi:10.5194/nhess-14-1361-2014.

Wang, Y., Z. Li, Z. Tang, and G. Zeng. 2011. A GIS-Based Spatial Multi-Criteria Approach for Flood Risk Assessment in the Dongting Lake Region, Hunan, Central China. Water Resources Management 25: 3465-3484. doi:10.1007/ s11269-011-9866-2

Yagoub, M.M. 2015. Spatio-temporal and hazard mapping of Earthquake in UAE (1984-2012): Remote sensing and GIS application. Geoenvironmental Disasters 2(1): 1-14.

Yahaya, S., N. Ahmad, and R.F. Abdalla. 2010. Multi-criteria analysis for flood vulnerable areas in Hadejia-Jama'are River basin, Nigeria. European Journal of Scientific Research 42(1): 71-83.

Yalcin, A. 2008. GIS-based landslide susceptibility mapping using analytical hierarchy process and bivariate statistics in Ardesen (Turkey): comparisons of results and confirmations. Catena 72(1): 1-12

Yalcin, G., and Akyurek, Z. 2004. Analyzing flood vulnerable areas with multicriteria evaluation, 6

Zazo, S., J.-L. Molina, and P. Rodríguez-G. 2015. Analysis of flood modeling through innovative geomatic methods. Journal of Hydrology 524: 522-537.

\section{Submit your manuscript to a SpringerOpen ${ }^{\circ}$ journal and benefit from:}

- Convenient online submission

- Rigorous peer review

- Immediate publication on acceptance

- Open access: articles freely available online

- High visibility within the field

- Retaining the copyright to your article

Submit your next manuscript at $>$ springeropen.com 